\title{
The redistributive potential of taxation in Latin America
}

\author{
Michael Hanni, Ricardo Martner and Andrea Podestá
}

ABSTRACT

This study uses internationally comparable methodologies to analyse the distributional impact of income tax and public transfers in 17 countries of Latin America. The results indicate that fiscal policy plays a limited role in improving the distribution of disposable income; the Gini coefficient decreased by barely three percentage points after direct fiscal action. On average, $61 \%$ of this reduction was due to public cash transfers and the rest to direct taxes, reflecting the pressing need for personal income tax to be strengthened. Analysis of household surveys gives an indication of the potential effects of tax reforms aimed at increasing the average effective tax rate of the top income decile. Allocating this additional revenue to targeted transfers would produce significant results. Consequently, tax reforms must be evaluated bearing in mind how those resources are used.

KEYWORDS

JEL CLASSIFICATION

AUTHORS
Taxation, income tax, income, income distribution, measurement, statistics, fiscal policy, Latin America

H22, H23, H24, H5, H55

Michael Hanni is an Associate Economic Affairs Officer with the Economic Development Division of ECLAC. michael.hanni@cepal.org

Ricardo Martner is the Chief of the Fiscal Affairs Unit of the Economic Development division of EcLAC. ricardo.martner@cepal.org

Andrea Podestá is a consultant with the Economic Development Division of EcLAc. andrea.podesta@cepal.org 


\section{I}

\section{Introduction}

Even though inequality in Latin American countries is an incontrovertible fact, public policies, particularly fiscal policies, have not had sufficient impetus to tackle the issue. ECLAC (2008) has found that social spending has a considerable impact on the lowest income groups, but not on inequality measurements. Reduction in inequality over the past decade has mainly been the result of a better distribution of labour income, with a much lesser redistributive role being played by the State.

Despite methodological difficulties and reliability issues with available data, the impact of fiscal policy has been studied for at least three decades in the region (see Gómez Sabaini and Morán, 2013). During the first decade of the twenty-first century, a series of studies were carried out on the impact of fiscal policy on Central American, Andean and other South American countries. ${ }^{1}$ The results showed that value added tax (VAT) had a modest redistributive, although regressive, effect, and that personal income tax was highly progressive, but had a very moderate redistributive effect, particularly when compared to the redistributive capacity of public social spending. It was thus concluded that fiscal policy overall was not playing a strong role in redistribution.

More recently, several papers have been published that examine the impact of spending and taxes on inequality and poverty in seven countries in the region: Argentina, Brazil, Mexico, Paraguay, Peru,

This paper is a summary of the first report on the draft ECLAC/ International and Ibero-American Foundation for Administration and Public Policies (FIIAPP) service contract as part of the EUROSOCIAL II programme, component IV: "Recent tax and public spending reforms in Latin America: distributory effects". The authors wish to thank Rodrigo Astorga and Ivonne González, as well as Xavier Mancero for his continued support in the analysis of household surveys, and Juan Pablo Jiménez, Michel Jorratt and an anonymous referee for their comments and suggestions.

1 These studies include the following countries: Plurinational State of Bolivia, Colombia, Ecuador, Peru and the Bolivarian Republic of Venezuela; Costa Rica, Dominican Republic, El Salvador, Guatemala, Honduras, Nicaragua and Panama; and Brazil, Chile, Paraguay and Uruguay. See the Inter-American Development Bank (IDB) Fiscal Equity Series: Barreix, Roca and Villela (2006); Barreix, Bes and Roca (2009), and Jorratt (2010).
Plurinational State of Bolivia and Uruguay. ${ }^{2}$ These studies consider the effects of direct and indirect taxes, indirect subsidies and transfers in cash and in kind, based on household surveys.

As part of a project undertaken by the United Nations Development Programme (UNDP) and the Canadian International Development Research Centre (IDRC), microsimulation models were developed (with and without behavioural changes) for five Latin American countries (Brazil, Chile, Guatemala, Mexico and Uruguay) with the aim of studying the impact of changes in direct and indirect taxes and social benefits on income distribution and poverty (Urzúa, 2012).

Similarly, the Organization for Economic Cooperation and Development (OECD) has published a series of studies on its member States. Joumard, Pisu and Bloch (2012) state that the redistributive impact of taxes and transfers depends on their size, mix and the progressivity of each component, and found that taxes and cash transfers reduced income inequality, as measured by the Gini index, by about $25 \%$ on average in OECD member countries towards 2010. In those countries, direct transfers reduce income dispersion more than taxes: three quarters of the reduction in inequality between market income and disposable income are due to transfers, the rest to taxes. Moreover, countries with a more unequal distribution of market income tend to redistribute more.

Against this backdrop, the first objective of this study is to calculate the impact of income tax and public cash transfers on the distribution of disposable income for a diverse group of 17 Latin American countries, using methodologies to obtain internationally comparable measurements. A second objective is to simulate the possible effects of potential reforms of tax systems, in order to demonstrate that tax instruments - and in particular that putting the resulting increase in revenue to good use- can have a significant impact on the distribution of disposable income.

This document has seven parts. Part II briefly describes the methodology used to measure the impact of fiscal policy. The results for both public cash transfers

\footnotetext{
${ }^{2}$ See Lustig, Pessino and Scott (2013), and Higgins and others (2013).
} 
and personal income tax are then analysed in part III. Part IV examines the redistributive effects of direct transfers disaggregated by population group. Part V assesses the progressivity and redistributive effects of personal income tax on disposable income. Part VI simulates and evaluates the effects of certain changes on this type of tax. Lastly, part VII reflects upon the reforms needed to improve fiscal action overall.

\section{II}

\section{Measuring the impact of fiscal action}

As in other studies available in the region, the methodology used consisted of applying a standard incidence analysis to determine how progressive or regressive the fiscal policy is and its effect on income redistribution. This type of static analysis does not take into account behavioural (for example, in the labour supply or in taxpayers' evasion or avoidance strategies) or life-cycle or general equilibrium effects. Therefore, it does not consider the reaction functions of economic agents with regard to the introduction or modification of taxes and transfers.

Broadly speaking, these types of studies compare income distribution before and after the payment of taxes or public transfers, or both, and thus determine whether tax systems, transfers and fiscal policy overall are fulfilling their redistributive roles.

The data used was taken from the most recent survey of household income and expenditure available for each country. However, it is well known that income data from household surveys are often underestimated owing to various factors, including the failure to capture the incomes of top earners, item or unit non-response and underreporting of income (particularly at the top end of the income distribution scale).

In general, given that underreporting and nonresponse is a common issue in household surveys, the income data have been adjusted by the Statistics and Economic Projections Division of ECLAC. Thus, in adjusting for non-response bias, each individual is imputed the average income declared by similar individuals; while underreporting of income is adjusted by multiplying income from each source by a factor equal to the discrepancy with the per capita income figure indicated in the national accounts. ${ }^{3}$ This procedure increases average income figures and generally alters

\footnotetext{
${ }^{3}$ For more details see the pioneering work of Altimir (1987).
}

their distribution too. In particular, it tends to yield higher values for inequality, chiefly owing to the fact that the capital income gap is imputed exclusively to the wealthiest quintile (ECLAC, 2012c). ${ }^{4}$

However, the adjustment for underreporting is not without its drawbacks and the availability and quality of data from national accounts varies depending on the country and period being studied. Countries also change their national accounts methodologies from time to time, changing either the base year of the series or the compilation methods. While these changes, which differ from country to country, undoubtedly improve the system of national accounts, they also affect household income and expenditure estimates to the extent that they alter some data sources, coverage of concepts and weightings between economic sectors and activities. Moreover, each new methodological approach is not just a simple rearrangement of the previous methodology; rather it modifies the treatment of certain items, incorporates new categories and eliminates old ones (ECLAC, 2012a). ${ }^{5}$

It is important to clarify some aspects of the methodology. The unit of analysis is the household and the well-being indicator is per capita income equivalent. The definition of income is that proposed by OECD (2008) so that the results are comparable across countries. Certain assumptions have been made with regard to the payment of taxes, since it is assumed that personal income tax is paid by the individual liable for the tax and that workers bear social security contributions in full, even if taxes are paid only in the formal sectors of the economy.

\footnotetext{
${ }^{4}$ It was not possible to adjust for the underreporting of income in the following countries: Colombia, El Salvador, Honduras, Nicaragua and Uruguay.

${ }^{5}$ ECLAC is currently in the process of reviewing the income adjustment methodology for national accounts in order to make it more consistent and to improve the comparability of results across countries and over time.
} 


\section{BOX 1}

PROGRESSIVITY AND REDISTRIBUTION INDICATORS

Income tax progressivity is determined on the basis of the tax payment share of each decile, the progression of average rates of tax and the Kakwani index.

The progression of average rates of tax indicates the amount of tax paid by each decile, expressed as a percentage of their income (effective tax rate). A tax is progressive when a higher income means that a greater proportion is paid in tax.

The Kakwani index compares the pre-tax Lorenz curve for income with the concentration curve for that tax, i.e.:

$$
\mathrm{K}=\text { quasi-Gini (tax) - Gini (pre-tax income) }
$$

If $\mathrm{K}$ is greater (less) than zero, the tax is progressive (regressive) and inequality decreases (increases).

The Reynolds-Smolensky index is an indicator of the redistributive capacity of the tax:

$$
\text { RS = Gini (pre-tax income) - Gini (post-tax income) }
$$

If $\mathrm{RS}$ is greater (less) than zero, it indicates that the tax has helped to reduce (increase) inequality.

The Atkinson-Plotnick index is used to measure the reranking effect, i.e., to assess whether individuals' pre-tax and post-tax rankings are the same:

$$
A-P=G(Y)-C X(Y)
$$

where $\mathrm{G}(\mathrm{Y})$ is the Gini coefficient of post-tax income and $\mathrm{CX}(\mathrm{Y})$ is the Gini coefficient of post-tax income, but with individuals ranked according to pre-tax income. If the index is zero, it means that they were not reranked and if it is 1 , the ranking has been completely inverted.

Source: Prepared by the authors.

\section{III}

\section{Results for 17 Latin American countries}

It is important to start the analysis by considering a hallmark of inequality in the region: the large proportion of total income that goes to the top decile, or the wealthiest $10 \%$ of households (see figure 1). On average, this group receives $32 \%$ of total income, although in Brazil, Chile, Guatemala, Honduras and Paraguay the figure is 10 percentage points higher than that, while in the Bolivarian Republic of Venezuela and Uruguay it is 10 percentage points lower.

There follows an analysis of the effects of personal income tax, social security contributions and public cash transfers on distributive equity. The results of the impact analysis are presented separately for public pensions and other public cash transfers, while the next section examines the redistributive effects of fiscal policy for people of working age and of retirement age.

The study considers 17 Latin American countries around 2011 and compares the results with OECD countries and, in particular, with the average for 15 European Union countries.

In addition, since personal income tax is an area in which the countries of the region are particularly weak, its impact on income distribution is analysed separately.

The results suggest that fiscal policy benefits lower income groups, mainly through public pensions and other direct cash transfers, since the effect resulting from income tax and social security contributions is more limited (see table 1 and figure 2). 
FIGURE 1

Latin America (18 countries): income share by decile grouping, around $2012^{\mathrm{a}}$ (Percentages)

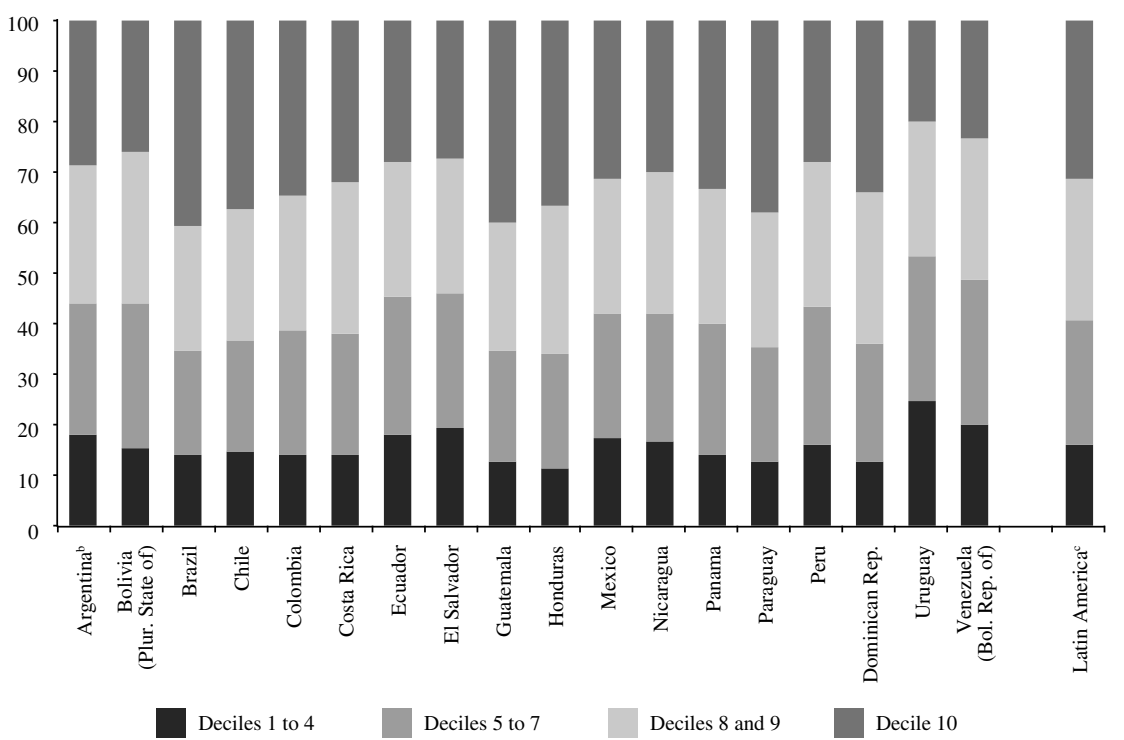

Source: Economic Commission for Latin America and the Caribbean (ECLAC), Social Panorama of Latin America 2013 (LC/G.2580), Santiago, 2013. United Nations publication, Sales No. E.14.II.G.6.

a Data refer to 2012, except those for Chile, Panama, Paraguay and Plurinational State of Bolivia (2011), Honduras (2010), Nicaragua (2009) and Guatemala (2006).

b Urban areas.

c Simple average.

TABLE 1

Latin America (17 countries): Gini coefficients before and after taxes and public transfers, around 2011

\begin{tabular}{|c|c|c|c|c|}
\hline Country & $\begin{array}{l}\text { Market income } \\
\text { (A) }\end{array}$ & $\begin{array}{c}\text { Gross income } \\
\text { with pensions only }(\mathrm{B}) \\
(\mathrm{B}=\mathrm{A}+\text { public pensions })\end{array}$ & $\begin{array}{l}\text { Gross income }(\mathrm{C}) \\
(\mathrm{C}=\mathrm{B}+\text { public } \\
\text { cash transfers })\end{array}$ & $\begin{array}{l}\text { Disposable income } \\
\text { in cash (D) } \\
(\mathrm{D}=\mathrm{C}-\mathrm{PIT} \text { - SSC) }\end{array}$ \\
\hline Argentina & 0.536 & 0.490 & 0.484 & 0.469 \\
\hline Bolivia (Plurinational State of) & 0.502 & 0.493 & 0.491 & 0.487 \\
\hline Brazil & 0.573 & 0.528 & 0.518 & 0.502 \\
\hline Chile & 0.546 & 0.526 & 0.510 & 0.499 \\
\hline Colombia & 0.531 & 0.537 & 0.531 & 0.520 \\
\hline Costa Rica & 0.528 & 0.510 & 0.503 & 0.491 \\
\hline Dominican Republic & 0.560 & 0.555 & 0.551 & 0.545 \\
\hline Ecuador & 0.481 & 0.467 & 0.461 & 0.453 \\
\hline El Salvador & 0.442 & 0.445 & 0.443 & 0.430 \\
\hline Honduras $^{\text {a }}$ & 0.551 & $\ldots$ & $\ldots$ & 0.546 \\
\hline Mexico & 0.496 & 0.494 & 0.484 & 0.460 \\
\hline Nicaragua & 0.465 & 0.464 & 0.465 & 0.452 \\
\hline Panama & 0.546 & 0.524 & 0.519 & 0.504 \\
\hline Paraguay $^{b}$ & 0.523 & 0.524 & 0.523 & 0.520 \\
\hline Peru & 0.487 & 0.485 & 0.482 & 0.461 \\
\hline Uruguay & 0.449 & 0.411 & 0.400 & 0.381 \\
\hline Venezuela (Bolivarian Republic of) & 0.393 & 0.384 & 0.384 & 0.379 \\
\hline
\end{tabular}

Source: Prepared by the authors, on the basis of household surveys.

Note: PIT: Personal income tax; ssc: Social security contributions.

a No information was obtained on the pensions and subsidies variables in the Honduras household survey, so their effect on the Gini coefficient could not be calculated.

b A simulation was used to calculate income tax in Paraguay based on the tax currently applicable. 
FIGURE 2

Latin America (17 countries), OECD and 15 European Union countries: inequality of market income, gross income and disposable income, around 2011

(Gini coefficients)

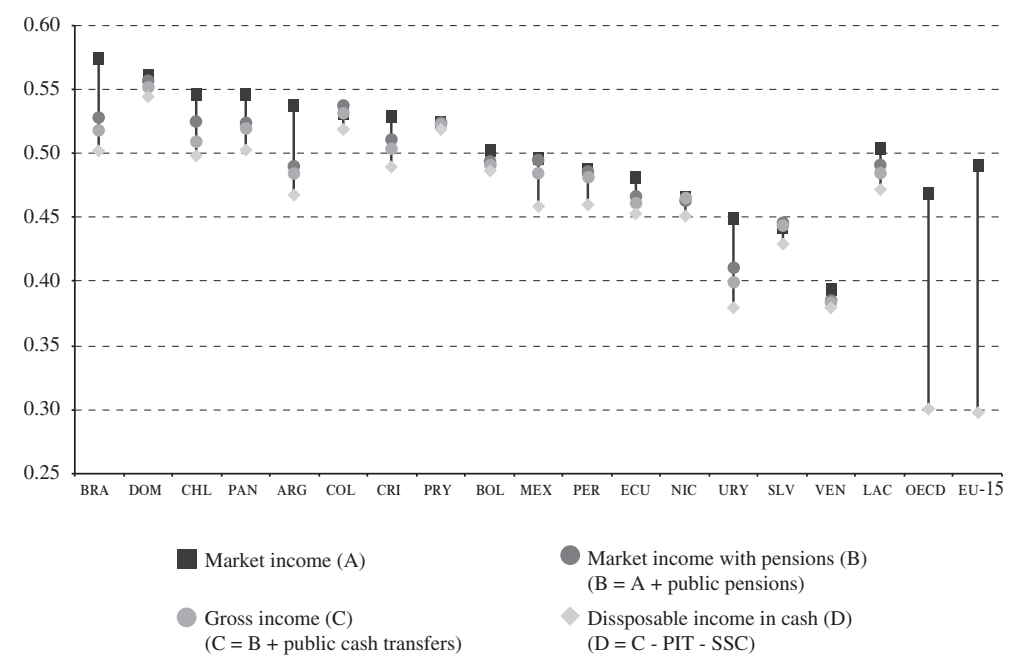

Source: Prepared by the authors, on the basis of household surveys for Latin America and OECD.Stat.

Note: PIT: Personal income tax; sSC: Social security contributions.

The figure for the Organization for Economic Cooperation and Development (OECD) is the average of 30 countries (excluding Chile and Mexico).

EU-I5: 15 European Union countries.

OECD: Organization for Economic Cooperation and Development.

LAC: Latin America and the Caribbean.

BRA: Brazil; DOM: Dominican Republic; CHL: Chile; PAN: Panama; ARG: Argentina; COL: Colombia; CRI: Costa Rica; PRY: Paraguay; BOL: Plurinational State of Bolivia; MEX: Mexico; PER: Peru; ECU: Ecuador; NIC: Nicaragua; URY: Uruguay; SLV: El Salvador; ven: Bolivarian Republic of Venezuela.

As expected, the effectiveness of fiscal policy in reducing inequality varies from country to country. Argentina, Brazil and Uruguay stand out with personal income tax, social security contributions and public cash transfers (including pensions) together reducing inequality (as measured by the Gini coefficient) by around $13 \%$ on average.

Fiscal policy also reduced inequality by more than the regional average in Chile, Costa Rica, Mexico and Panama, primarily as a result of transfers and direct subsidies, such as the Oportunidades programme in Mexico, Chile Solidario (Solidarity Chile), Avancemos in Costa Rica or the Opportunities Network in Panama. An equalizing effect was also achieved by public pension programmes in Chile, Costa Rica and Panama, and by direct taxation in Mexico.

At the other end of the scale are Colombia and Paraguay, where public cash transfers and direct taxes have had only a small impact on income distribution, since the Gini index decreases by less than $2 \%$ after fiscal action. These countries are also among those with the greatest market income inequality and those in which, accordingly, fiscal policy should in fact be more redistributive. Conversely, OECD countries with a more unequal market income distribution tend to redistribute more (Joumard, Pisu and Bloch, 2012). Brazil, Chile and Argentina have high pre-fiscal inequality, which is partly corrected through public pensions, transfer programmes and direct taxes.

Regardless of the differences between countries, in all cases public cash transfers (such as conditional transfer schemes and others) and personal income tax reduce income distribution inequality to varying degrees (see figure 3). In general, public pension systems also contribute to a more equal distribution, except in three countries where pensions increase inequality (Colombia, El Salvador and Paraguay). 
Latin America (17 countries): inequality reduction, by fiscal policy instrument, around 2011

(Percentage points of the Gini coefficient)

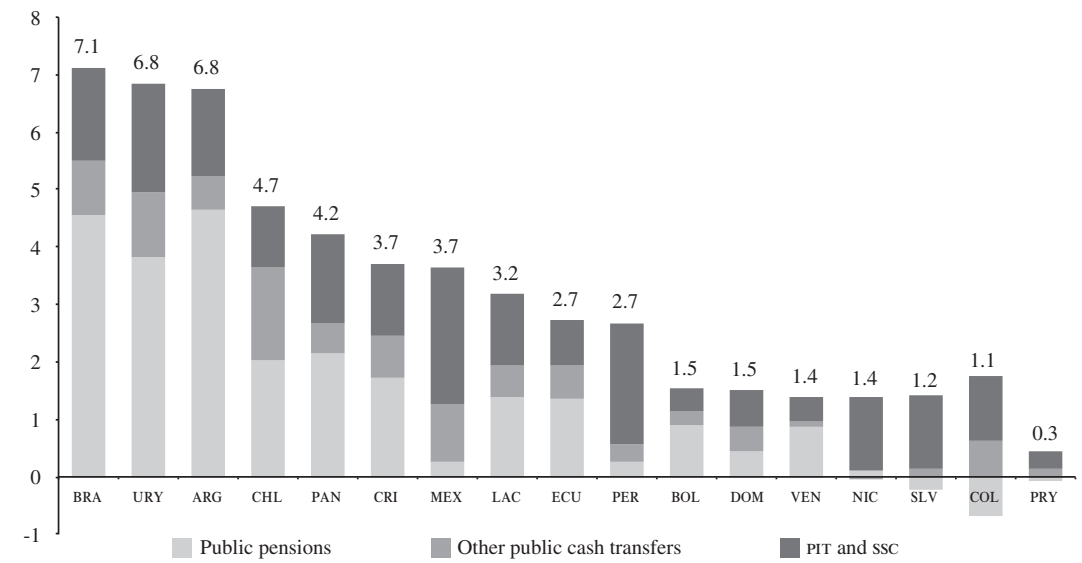

Source: Prepared by the authors, on the basis of household surveys.

Note: PIT: Personal income tax; ssc: Social security contributions.

LAC: Latin America and the Caribbean.

BRA: Brazil; DOM: Dominican Republic; CHL: Chile; PAN: Panama; ARG: Argentina; COL: Colombia; CRI: Costa Rica; PRY: Paraguay; BOL: Plurinational State of Bolivia; MEX: Mexico; PER: Peru; ECU: Ecuador; NIC: Nicaragua: URY: Uruguay; sLv: El Salvador; vEN: Bolivarian Republic of Venezuela.

On average, public cash transfers (including pensions) are responsible for $61 \%$ of the reduction in the Gini coefficient of market income and the rest of the decrease is the effect of income tax and the payment of social security contributions. This finding - that public transfers play a greater redistributive role than direct taxes- is consistent with those of other regional studies.

One advantage of the methodology used for these estimates is that it follows the OECD approach for the different definitions of income, which allows for comparison between the two groups of countries. Figure 2 illustrates the large difference in the role fiscal policy plays in reducing income inequality. The Gini coefficient of market income (i.e. before transfers and direct taxes) in Latin American countries is initially slightly higher than the OECD average ( 0.50 and 0.47 , respectively). However, in OECD countries fiscal policy is important in reducing inequality, since the Gini coefficient drops 36\% (39\% on average in the 15 European Union countries) and stands at 0.30 (in absolute terms, the Gini coefficient decreases by 17 percentage points in OECD countries and 19 points in the 15 European Union countries). In contrast, inequality in Latin America and the Caribbean dropped by just $6 \%$ on average (or in absolute terms, by 3 Gini points for the 17 countries on average), bringing the Gini for disposable income to 0.47 on average (the same as the Gini coefficient for OECD market income).
The disparities between the two groups of countries can also be seen in figure 4, which charts the Gini coefficient before and after transfers and direct taxes. The vast majority of Latin American countries remain close to the $45^{\circ}$ line, as fiscal policy has little effect on the Gini coefficient. Conversely, OECD countries are well below this line, which indicates that fiscal instruments have a much more significant impact.

One reason for this difference in the power of fiscal policy to improve income distribution is the lower tax burden in Latin America which, although it has improved in recent years, is still well below the levels of OECD countries. ${ }^{6}$ This lower tax burden limits the level of public and social spending and, therefore, the extent to which fiscal policy affects the income of the lowest strata. Not only is the tax burden different, but the tax structure is too: in the Latin American countries the structure relies heavily on indirect taxes, while in OECD countries a significant proportion of tax is levied directly, particularly through personal income tax, which has a greater redistributive impact. For example, the revenue raised by personal income tax averaged $8.4 \%$ of gross domestic product (GDP) in OECD, compared to just $1.4 \%$ in Latin America and the Caribbean.

\footnotetext{
${ }^{6}$ See ECLAC (2013a) and OECD/ECLAC/CIAT (2014).
} 
FIGURE 4

Latin America, OECD and 15 European Union countries: inequality of market income and disposable income, around 2010 and 2011

(Gini coefficients)

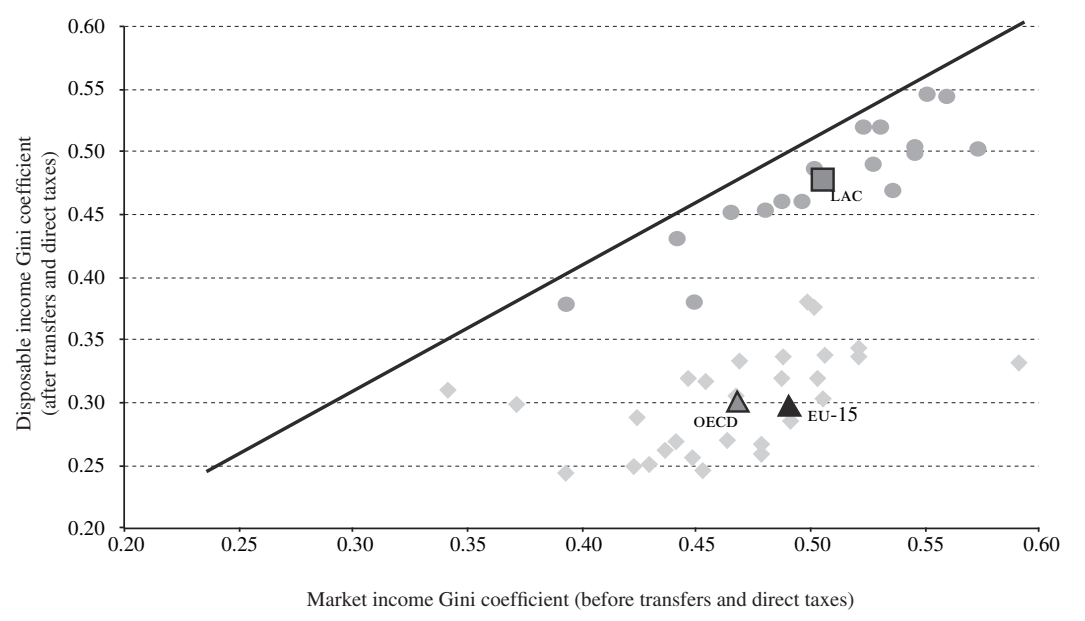

Source: Prepared by the authors, on the basis of household surveys for Latin America and OECD.Stat.

Note: The lighter coloured triangle represents the average for OECD countries, the darker triangle is the average for the 15 European Union countries and the square is the average for Latin America. The circles represent Latin American and Caribbean countries, the diamonds OECD countries.

EU-I 5: 15 European Union countries.

OECD: Organization for Economic Cooperation and Development.

LAC: Latin America and the Caribbean.

The difference in social security coverage between countries of the region and OECD members is another factor in the different impact of fiscal policy. A significant percentage of older adults in countries with broad coverage receive a non-contributory pension: Uruguay with $11 \%$; Argentina with 25\%; Chile with 26\%; and Brazil with 36\% (Bosch, Melguizo and Pagés, 2013). The results reported here show that pensions have a stronger impact on inequality in those four countries and in Costa Rica than in other Latin American countries.

Another indicator used to assess the impact of transfers and direct taxes is the ratio between the average income of the top and bottom deciles, for the various categories of income (see table 2). This data can be used to supplement analysis of the Gini coefficients, because, as most public transfer programmes target the most vulnerable groups (the lower income deciles) and personal income tax is obtained mainly from the top two deciles, the distribution is largely unchanged.

According to this indicator, in several countries social security benefits increase the income of the top $10 \%$ more than the income of the bottom $10 \%$, making income distribution more uneven. The opposite happens with direct public transfers, which benefit in particular the lowest income decile and are thus the instrument with the greatest redistributive power. Brazil, Costa Rica, Mexico and Panama are among the countries whose transfer schemes have the strongest impacts, with larger drops in the income ratio. After payment of income tax and social security contributions, the ratio between the income of the top and bottom deciles drops again, with the most significant decreases occurring in Brazil, Chile, Costa Rica and Mexico.

The final average effect of tax action in the countries of the region indicates that the income of the top decile is 34 times that of the bottom decile for market income and 28 times for disposable monetary income (after transfers and direct taxes). While this implies a reduction in income inequality between the top and bottom deciles, the region falls far short of OECD and the European Union countries in this regard, where the average income for the top $10 \%$ is only eight times that of the bottom $10 \%$, after taxes and direct transfers. 
TABLE 2

Latin America (17 countries): average per capita income ratio between the top and bottom deciles, around 2011

(Multiples)

\begin{tabular}{|c|c|c|c|c|}
\hline Country & $\begin{array}{c}\text { Market } \\
\text { income (A) }\end{array}$ & $\begin{array}{c}\text { Market income } \\
\text { with pensions }(\mathrm{B}) \\
(\mathrm{B}=\mathrm{A}+\text { public pensions })\end{array}$ & $\begin{array}{l}\text { Gross income }(\mathrm{C}) \\
(\mathrm{C}=\mathrm{B}+\text { public } \\
\text { cash transfers })\end{array}$ & $\begin{array}{l}\text { Disposable income } \\
\text { in cash (D) } \\
(\mathrm{D}=\mathrm{C}-\mathrm{PIT}-\mathrm{SSC})\end{array}$ \\
\hline Bolivia (Plurinational State of) & 51.2 & 51.1 & 47.5 & 46.1 \\
\hline Brasil & 52.0 & 58.7 & 38.2 & 34.2 \\
\hline Chile & 33.1 & 31.6 & 27.7 & 24.7 \\
\hline Colombia & 34.6 & 39.1 & 36.1 & 33.7 \\
\hline Costa Rica & 39.8 & 36.9 & 32.4 & 29.5 \\
\hline Dominican Republic & 47.7 & 47.7 & 43.9 & 41.9 \\
\hline Ecuador & 28.4 & 25.2 & 23.3 & 21.9 \\
\hline El Salvador & 17.9 & 18.7 & 18.3 & 16.8 \\
\hline Honduras ${ }^{\mathrm{a}}$ & 40.6 & $\ldots$ & $\ldots$ & 39.2 \\
\hline Mexico & 27.9 & 28.6 & 24.1 & 20.8 \\
\hline Nicaragua & 21.8 & 22.2 & 22.3 & 20.7 \\
\hline Panama & 43.8 & 44.5 & 38.9 & 34.8 \\
\hline Peru & 35.1 & 36.5 & 33.3 & 29.0 \\
\hline Uruguay & 15.6 & 15.0 & 13.0 & 11.3 \\
\hline Venezuela (Bolivarian Republic of) & 13.8 & 14.4 & 14.3 & 13.8 \\
\hline
\end{tabular}

Source: Prepared by the authors, on the basis of household surveys.

Note: PIT: Personal income tax; ssc: Social security contributions.

a No information was obtained on pensions and subsidies variables in the Honduras household survey, so their effect on the Gini coefficient could not be calculated.

b A simulation was used to calculate income tax in Paraguay based on the tax currently applicable.

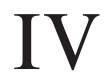

\section{Impact of public cash transfers by population group}

It is useful to calculate the redistributive effect of fiscal action by population group, since this enables analysis of the impact on the working age population and on older people (see figure $5 \mathrm{~A}$ and $\mathrm{B}$ ).

In recent decades, several countries in the region have reformed their pensions systems and introduced private individual capitalization funds. These private models are relatively new, so, in general, most beneficiaries of old age pensions are covered by the public system and their pension is their main or only source of income. As a result, it is expected that the effects of public cash transfers will have a greater impact on people aged over 65 .

In Latin America, as in OECD countries, cash transfers and direct taxes tend to reduce inequality among older adults, with the Gini coefficient for this age group decreasing from 0.57 to 0.47 in Latin American countries and from 0.73 to 0.28 in OECD countries. However, with regard to the working-age population, inequality in market incomes is lower to start with, and the Gini coefficient drops considerably less: from 0.49 to 0.47 in Latin America and from 0.42 to 0.30 on average in OECD countries.

With regard to the results by country, in the case of the working-age population, transfers and direct taxes had the strongest impact in terms of reducing market income inequality in Uruguay, Brazil and Argentina, followed by Mexico, Panama, Chile and Costa Rica. 
FIGURE 5

Latin America (16 countries), OECD and 15 European Union countries: inequality of market income, gross income and disposable income by age group, around 2011 (Gini coefficient)

A. Retirement age population

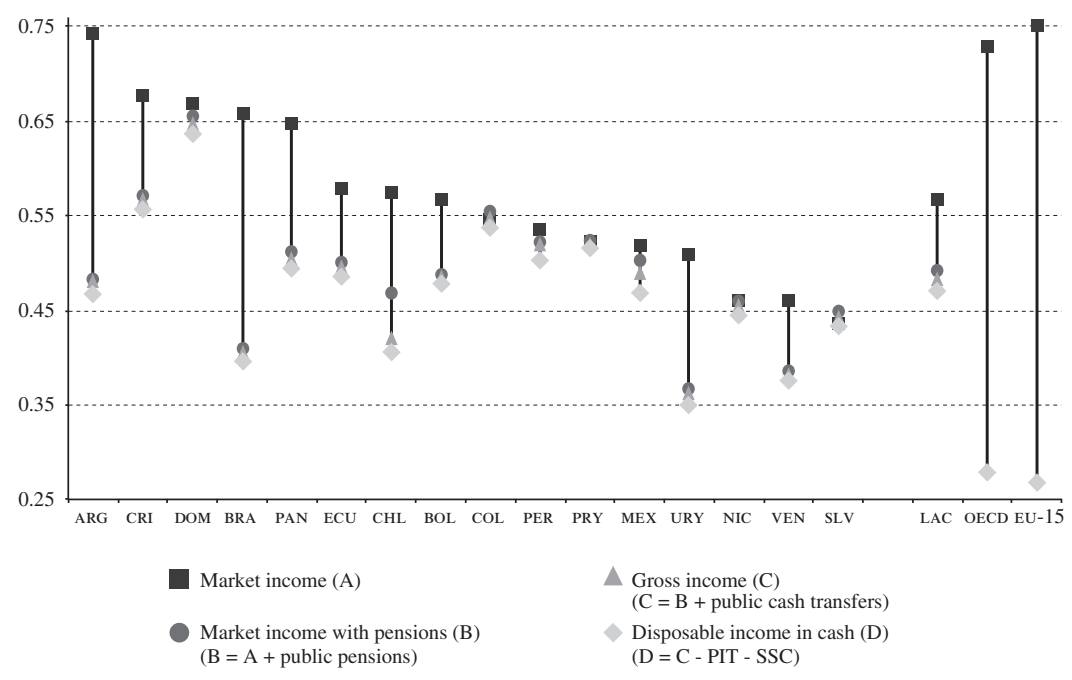

B. Working age population

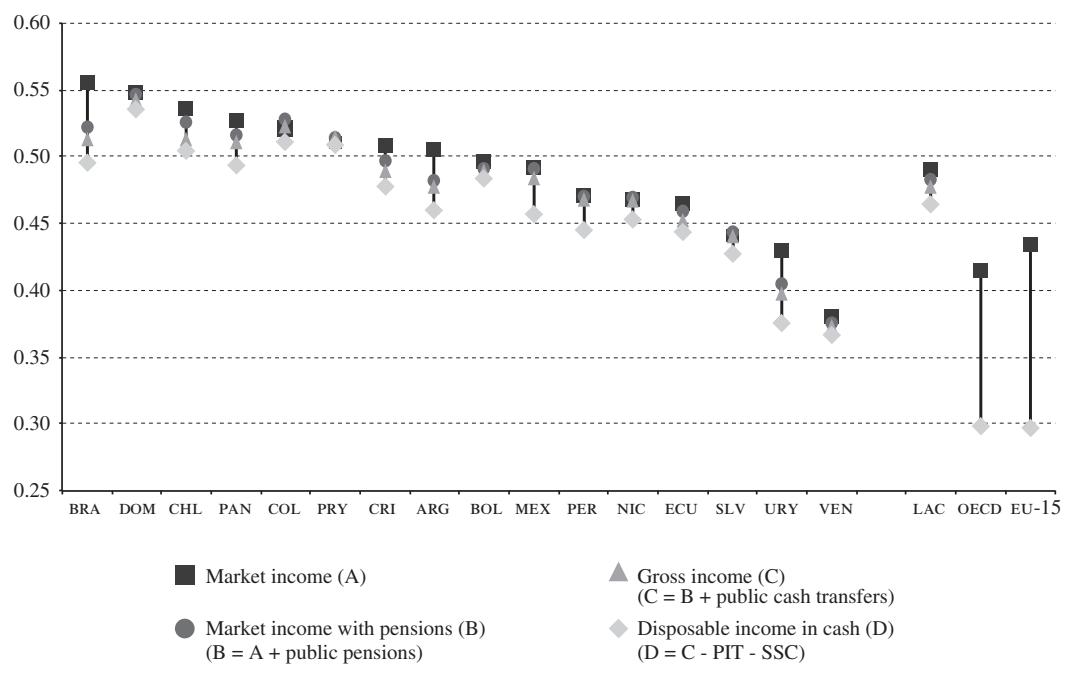

Source: Prepared by the authors, on the basis of household surveys.

Note: PIT: Personal income tax; sSC: Social security contributions.

The figure for the Organization for Economic Cooperation and Development (OECD) is the average for 30 countries (excluding Chile and Mexico)

EU-I 5: 15 European Union countries.

OECD: Organization for Economic Cooperation and Development.

LAC: Latin America and the Caribbean.

BRA: Brazil; DOM: Dominican Republic; CHL: Chile; PAN: Panama; ARG: Argentina; COL: Colombia; CRI: Costa Rica; PRY: Paraguay; BOL: Plurinational State of Bolivia; MEX: Mexico; PER: Peru; ECU: Ecuador; NIC: Nicaragua; URY: Uruguay: SLV: El Salvador; vEN: Bolivarian Republic of Venezuela. 


\section{BOX 2}

PENSION SCHEME ANALYSIS IN IMPACT STUdIES

Pension scheme analysis is a complex and controversial matter in these sorts of studies. In the countries of the region there are public pension systems and private ones, as well as contributory and non-contributory pensions. This can affect international comparisons, given that pensions could be considered market income or a public cash transfer.

For this study, we have followed the criterion used in OECD (2008), which includes occupational and private pensions in the definition of market income, while pensions from public social security systems are treated as cash transfers, i.e. as part of gross income. According to Lustig, Pessino and Scott (2013), there are arguments for treating contributory pensions as either part of market income, because they are deferred income, or a government transfer, especially in systems with a large subsidized component.

As far as the information available in surveys allows, additional impact analysis was carried out treating contributory pensions from public social security systems as part of market income. In this case, the effect of public transfers through pensions decreases considerably in Brazil and Uruguay (but not in Argentina). However, these countries are still among those with the most redistributive fiscal action, with a combined impact (under this alternative measurement) similar to that achieved in Chile and Mexico.

Source: Prepared by the authors.

Among the retirement age population, Brazil, Argentina, Uruguay and Chile stand out, with a drop in the Gini coefficient of $30 \%$ or more, while in Panama, Costa Rica, the Bolivarian Republic of Venezuela, Ecuador and the Plurinational State of Bolivia inequality decreases by between $15 \%$ and $23 \%$. This highlights the strong influence of pension transfers on the difference between the market income and the disposable income Gini for those aged 65 and over, especially in countries with a high dependency rate of older adults, primarily in Argentina and Uruguay (see figure 6).

It is clear, then, that the degree of coverage of public pension systems has a high impact on the redistribution of disposable income (although this also depends on each country's dependency rate), and it is therefore not surprising that the impact of transfers is minimal in countries with low pension coverage (see Bosch, Melguizo and Pagés, 2013). Fiscal action clearly has a greater impact on income distribution in those countries where significant steps have been taken towards universal pension coverage, as most older adults lack substantial sources of income of their own.

However, such interventions will very likely be insufficient, given that inequality remains an unresolved issue for both the working age population and older people. 
FIGURE 6

Latin America (16 countries): ratio between the decrease in the Gini coefficient as a result of public pensions and dependency rate of older persons

(Retirement age population)

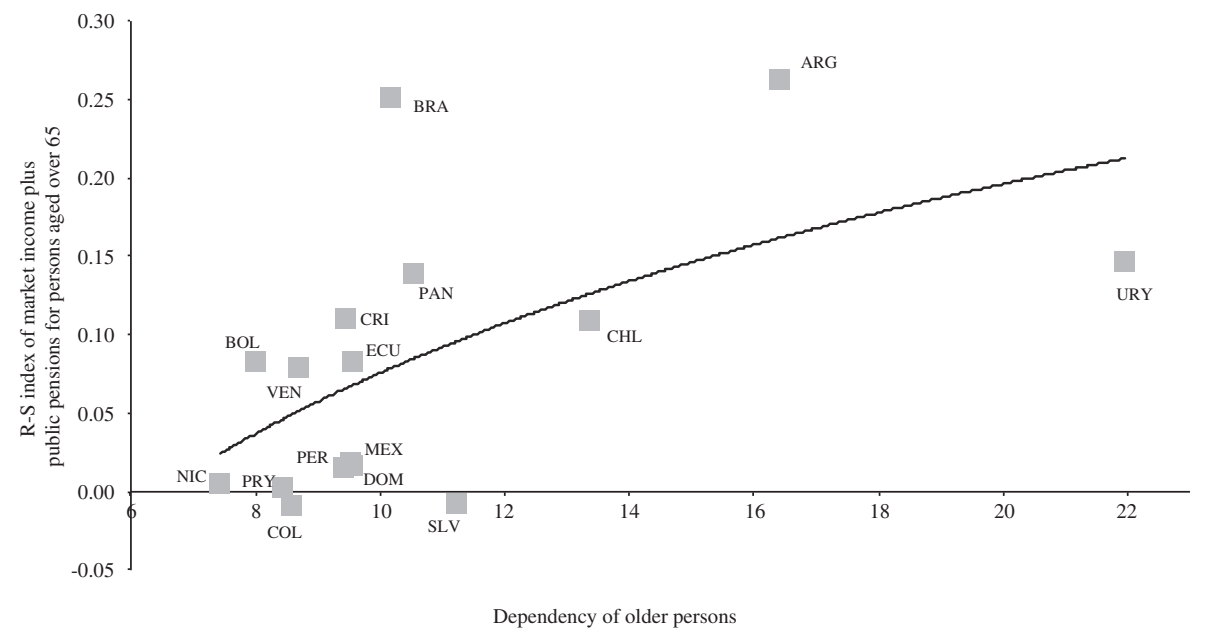

Source: Prepared by the authors, on the basis of household surveys and the Latin American and Caribbean Demographic Centre (CELADE)Population Division, population database.

Note: R-s Reynolds Smolensky.

BRA: Brazil; DOM: Dominican Republic; CHL: Chile; PAN: Panama; ARG: Argentina; col: Colombia; CRI: Costa Rica; PRY: Paraguay; BOL: Plurinational State of Bolivia; MEX: Mexico; PER: Peru; ECU: Ecuador; NIC: Nicaragua; URY: Uruguay; SLV: El Salvador; ven: Bolivarian Republic of Venezuela.

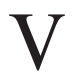

\section{Progressivity and redistributive impact of personal income tax}

In order to assess the progressive or regressive nature of personal income tax, the average rates of tax paid by each decile must be calculated first. In general, the higher the income level (upper deciles), the higher the proportion of taxes paid, i.e. the personal income tax is progressive (see table 3). However, the progression curve of average rates does not always rise (for example, in the case of Colombia and Paraguay), so the Kakwani index is also calculated, which finds personal income tax to be progressive - with a positive value - in all the countries.

In most countries, $90 \%$ or more of income tax is levied on the $20 \%$ with the highest incomes, while the remaining $80 \%$ of lower income households do not contribute to tax revenue or do so to a very small extent.

Nevertheless, the effective rate of tax paid by individuals in the top decile is just $5.4 \%$ on average, with the highest earners paying between $1 \%$ and $3 \%$ in tax on their gross income in some countries. Although the maximum legal rates for personal income tax range between $25 \%$ and $40 \%$, the actual rates paid by the top decile are very low as a result of tax evasion and avoidance, exemptions, deductions and the preferential treatment afforded to capital income, which is taxed at a lower rate than labour income in some countries and not taxed at all in others.

Consequently, although the personal income tax is designed to be progressive in all countries, its redistributive impact is very limited owing to the low levels of collection. In other words, the action of personal income tax reduces the Gini coefficient by an average of $2 \%$ (or, in absolute terms, one percentage point of the Gini coefficient), with certain variations from country to country. 
The Atkinson-Plotnick index is used to assess whether the distribution of income tax alters the ranking of individuals by income level. In the Bolivarian Republic of Venezuela, Ecuador, Honduras and Paraguay, the ranking of taxpayers is practically unchanged. Conversely, individual ranking changes substantially as a result of personal income tax action in Argentina, Mexico and Uruguay.

\section{BOX 3}

IMPACT OF VALUE ADDED TAX (VAT) AND TAX SYSTEMS OVERALL

VAT is widely known to be the main tax in all countries of the region, but its design and impact on income distribution varies from country to country, since some have standard rates (Chile, El Salvador), and others variable rates (Argentina, Colombia) and in still others, staple goods are exempt from VAT (Mexico, Costa Rica, Dominican Republic) (for details on the different systems, see ECLAC, 2013a). Studies available for Latin America take into account the strong regressive nature of VAT in countries such as Brazil, Chile, El Salvador, Guatemala, Paraguay, Plurinational State of Bolivia and Uruguay. In Uruguay, the study predates VAT exemption measures for the beneficiaries of social programmes, which have been in force since 2012 .

In countries that have data on the Gini coefficient before and after direct and indirect taxes, nowhere does the redistributive impact of tax systems overall exceed $1.5 \%$, and the Reynolds-Smolensky index is between -0.008 and 0.009 in all cases. In other words, tax policy action does not change income distribution in the region significantly, in part owing to the low collection rate of income tax and in part because of the regressive nature of VAT, which offsets the potentially progressive impact of personal income tax.

Source: Economic Commission for Latin America and the Caribbean (ECLAC), "Fiscal panorama of Latin America and the Caribbean: towards greater quality in public finance" (LC/L.3766), Santiago, 2014. 


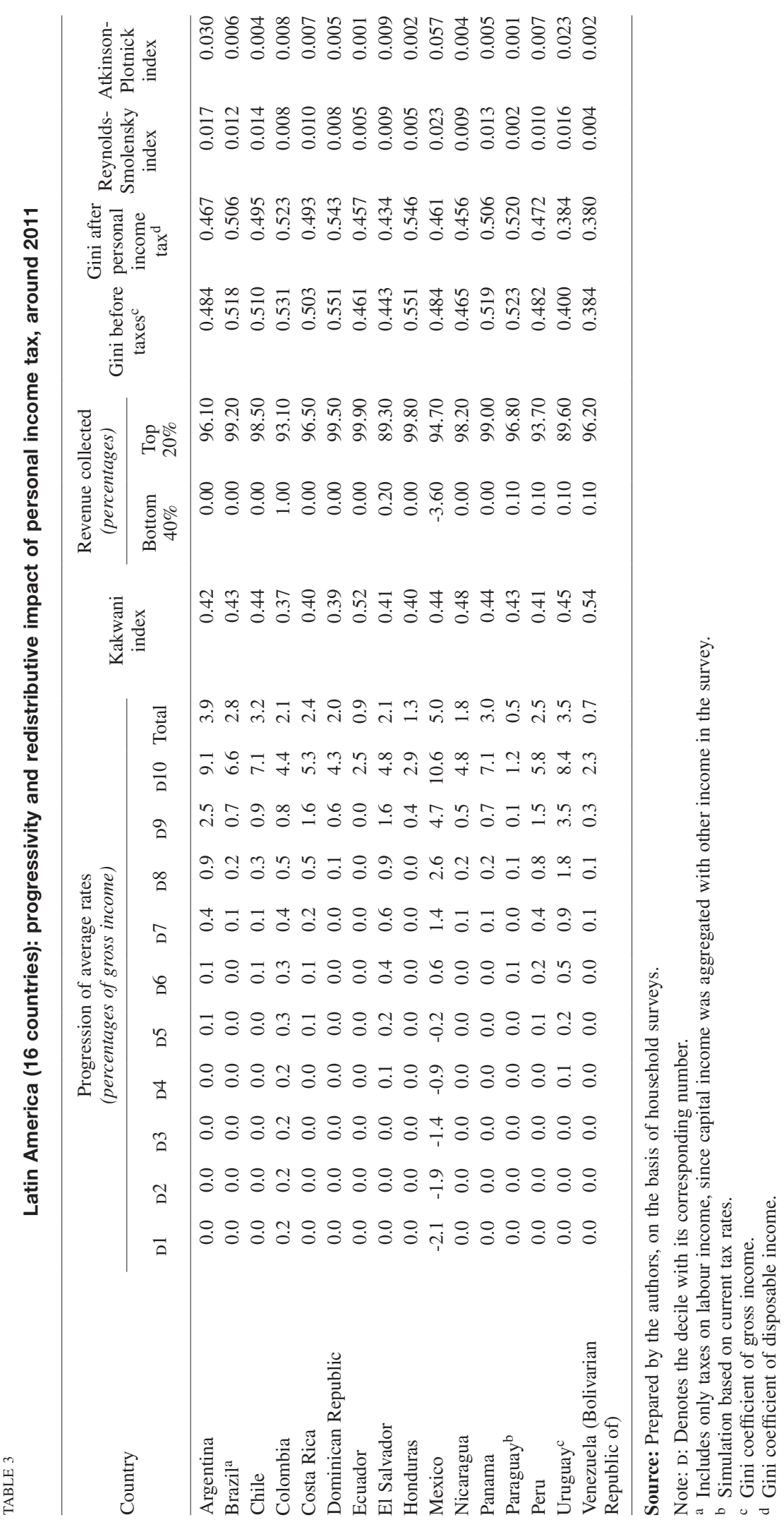




\section{VI}

\section{Policy simulations}

As has been stressed in numerous documents and forums, the relative and absolute weakness of income tax is the main structural problem affecting tax systems in Latin America. Tax policy has prioritized efficiency, striving to ensure that income tax should have as little impact as possible on savings and investment decisions and, in some cases, moving towards a consumption base rather than the traditional income-based system.

In doing so, the attributes of fairness and simplicity have been sacrificed. The main issue undermining the fairness of income tax is the preferential treatment afforded to capital income, which leads to an asymmetry in respect of the taxation of labour income. The fairness of income tax is also undermined by its treatment of individuals rather than households as the unit of taxation, which encourages income splitting in order to reduce tax liabilities, and by income exemptions that benefit higher earners (see Jorratt, 2011).

In the past decade, several countries in the region have undertaken a series of tax reforms with a view to increasing receipts by raising rates, cutting exemptions, implementing dual taxation systems in some cases, modifying or introducing minimum rates and increasing oversight of the highest taxpayers. ${ }^{7}$ However, the impact of these reforms on inequality remains very limited in most countries, as recent studies by ECLAC have shown. ${ }^{8}$ In order to make tax significantly fairer, taxation on capital income and average effective rates of the top deciles or percentiles, which are comparatively low, must be increased.

It is therefore important to consider reforms from the perspective of a fair distribution of disposable income and, to that end, certain scenarios of personal income tax reform have been examined, as set out below: ${ }^{9}$

(i) Repeal the main tax expenditures that benefit natural persons, without changing the tax brackets or marginal rates. In other words, all earned income is taxed, including capital and transfers from any source. In

\footnotetext{
${ }^{7}$ For a detailed description of the reforms implemented in the region between 2007 and 2013, see ECLAC (2014a and 2013a).

8 Studies for Chile, Ecuador, El Salvador, Guatemala, Honduras, Peru and the Plurinational State of Bolivia show that the impact of income tax reforms on income distribution has been rather limited.

9 More details can be found in Jorratt (2011), who used similar simulations for some countries in the region.
}

countries where different rates of personal income tax are applied depending on income source, the brackets and progressive rates imposed on labour income will be applied to all types of income.

(ii) Family income tax ${ }^{10}$ where:

- The taxation unit is the household rather than the individual.

- The same tax base as in scenario (i) is used, but expressed as equivalent income and to which the current tax rate scale is applied.

- All the rate brackets are adjusted by the same factor, so that revenue is equal to that obtained under scenario (i).

(iii) Standard tax: the use in all countries of the same tax brackets on a broad tax base, without tax expenditures, in order to compare the redistributive potential of the tax in different countries. The same tax base as scenario (i) is used and the personal tax brackets of each country are replaced with a common scale. Of course the Gini coefficient barely moves in simulations that marginally affect the income of the top or bottom deciles, as is the case in these exercises. In other words, from a tax point of view, instead of simulating detailed measures, it is also interesting to reverse the exercise, assuming that the average effective tax rates can be increased for the highest deciles - without specifying how-, in order to then calculate the impact on income distribution. ${ }^{11}$ Two additional simulations are therefore included:

(iv) Based on scenario (i), the effective rate for the top decile is increased to $20 \%$. For this purpose, it is assumed that informal workers in the top decile pay personal income tax.

(v) In addition to applying an effective rate of $20 \%$ to decile 10 , the tax burden on deciles 8 and 9 is increased to $10 \%$, also on the basis of scenario (i).

\footnotetext{
${ }^{10}$ While this measure may be difficult to apply in practice, as part of this study a series of exercises were carried out to assess a wide range of possible reforms, regardless of their legal feasibility.

11 This is far from a pointless exercise, for example, in Chile, the 2014 tax reform seeks to more than double the average effective tax rate for decile 10 , by changing rates, phasing out of exemptions and introducing greater controls. The new effective rate of tax for that decile should be in excess of $20 \%$, similar to the rate in the European Union (see document "Artículo 1, el corazón de la Reforma Tributaria" [online] http://reformatributaria.gob.cl/documentos.html).
} 
In addition, the effect of redistributing the higher revenue raised through cash transfers was calculated for each of the five scenarios, compared to the current situation. As they are static simulations - which do not take into account second-round effects- there is no need to specify how these additional resources are allocated, since it is assumed that they would be distributed equally among individuals belonging to the three lowest income deciles.

The results indicate that there is ample room to improve the redistributive power of personal income tax in Latin America (see figure 7). Vertical and horizontal equity improves when the main tax expenditures of income tax are phased out (even without considering the impact of redistributing additional revenue). Switching to a family tax regime, inequality decreases a little more. ${ }^{12}$ Applying a standard tax (scenario (iii)) in all countries, across a broad tax base, also improves the redistributive function of income tax, although it does change the ranking of individuals (Atkinson-Plotnick index) to a greater extent.

\footnotetext{
12 The greater redistributive effect of the family tax is in line with the results obtained by Jorratt (2011) in his simulations for Ecuador, Guatemala and Paraguay.
}

FIGURE 7 Average effective rate of tax of the top $10 \%$, redistribution and reranking impact
of personal income tax under different scenarios
(Average for Latin America)

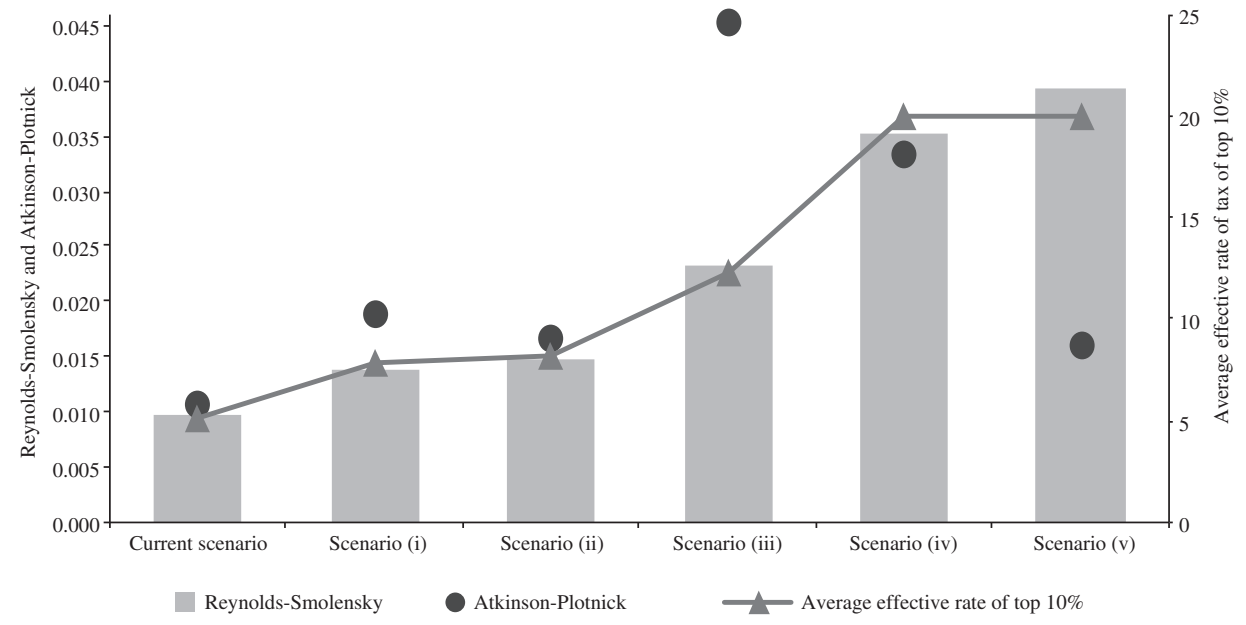

Source: Prepared by the authors, on the basis of household surveys.

Note: Scenarios without redistributing additional revenue to the lower deciles. Scenarios: (i) Personal income tax without tax expenditures; (ii) Family tax; (iii) Standard tax; (iv) 20\% tax rate on decile 10, and (v) 20\% tax rate on decile 10 and $10 \%$ on deciles 8 and 9.

If the countries of the region managed to increase the effective tax rate for the top decile on the income scale up to $20 \%$, the redistributive effect of personal income tax, measured by the Reynolds-Smolensky index, would increase considerably. This increase in the effective rate is achieved by eliminating the major tax expenditures, taxing capital income the same as labour income, and assuming no tax evasion. According to the study's estimates, to achieve such an effect, the average statutory rate imposed on taxpayers in the top decile would have to be between $20 \%$ and $30 \%$, depending on the country. These values are below or close to the maximum rates provided for in national legislation, with the exception of Paraguay, which has a maximum statutory rate of $10 \%$.

Taxing deciles 8 and 9 at an average effective rate of $10 \%$ also reduces inequality.

The results of the last two scenarios expose specific weaknesses in personal income tax in the countries of the region, in particular the high level of tax evasion 
and avoidance, tax structures that tend to leave some income untaxed and the high level of income that must be earned before the top rate of tax is applied.

Although in the first scenarios - which retain, in part or in full, the existing tax brackets and ratesbroadening the tax base increases the average effective rates, particularly for the higher deciles, the rates remain relatively low (see figure 7). The reasons for this include the fact that, unlike OECD countries, the countries of the region have reduced their top marginal tax rates, bringing them in line with the rates for companies (Cetrángolo and Gómez Sabaini, 2007). This factor is exacerbated by the high income level from which these rates are applied. On average, the top rate in Latin America applies to incomes that are nine times per capita GDP, compared with 6.5 times in the group of middle-income countries overall (Ter-Minassian, 2012). The results of the last two scenarios and, to a lesser extent, scenario (iii) show that increasing average effective rates —overcoming certain weaknesses in the current tax structure by reducing tax evasion - would lead to greater income redistribution.

A common argument against reforms such as those simulated in this study, is that they could reduce tax progressivity, since the aim of the tax deductions permitted in most countries is to make the system more progressive. The decrease in the Kakwani index in the scenario where the main tax expenditures were eliminated appears to validate this argument (the indicator falls from an average of 0.44 to 0.37 ). However, according to Díaz de Sarralde, Garcimartín and Ruiz-Huerta (2010), Kakwani decomposition may not be suitable when analysing tax reforms which, like those examined here, increase revenue because, as the calculation of the Kakwani index is influenced by changes in the average effective rate, a drop in the index could indicate a decrease in tax progressivity or simply a change in the average effective rate, as is the case in these simulations. Thus, expanding the tax base leads to an increase in effective tax rates, particularly in the two highest income deciles, and the redistributive effect is greater than under the existing system (see figure 7).

In fact, in the scenarios under consideration, greater vertical equity was achieved by significantly increasing average effective rates. It should also be noted that the increase in these rates is due to higher deciles paying a larger share of tax in relation to their income and that the differential between the rates paid by the upper and lower deciles widens as a result of these measures.

In turn, the effects on the Gini coefficient are relatively minor in the scenarios described above, where the resources generated by a higher tax take are not redistributed. It is often said that, on the basis of such exercises, the impact of tax systems - particularly income tax - on income distribution is relatively small, but it is important to calculate the overall effect, bearing in mind the end use of those resources.

The increase in effective rates, together with the subsequent redistribution of that revenue among the three lower deciles, would produce a reduction in the average Gini coefficient for the region ranging from 3 percentage points, in the case of family tax and taxation without tax expenditures, to 13 percentage points in the scenario of raising the effective rate for the three highest earning deciles (see figure 8). Thus, the Gini coefficient of average disposable income for the region would be between 0.45 and 0.36 , depending on the policy scenario. The latter figure is quite close to the average rate for OECD countries or the 15 European Union countries considered, which stands at 0.30 .

Since the income tax burden falls more heavily on the top decile, the income of that group drops, on average, from 29.5 to 27.9 times the income of the bottom decile in the current system for countries in the region (see figure 9). Eliminating the main deductions and exemptions and other policy options reduces this ratio to 26 or 27 , depending on the scenario, while the simulations that increase the effective rate for the top decile to $20 \%$, reduce the average income of that decile to 23.6 times that of the lowest decile.

The net effect of these policies, that is, when the additional revenue is redistributed among the lowest three deciles, places this ratio between 21 and 7 depending on the policy scenario used. The latter figure implies a significant decrease in income inequality between the highest and lowest deciles, and leaves the region with an income ratio similar to the average for OECD countries and the 15 European Union countries considered (whose ratios are 8.3 and 7.8 , respectively). 
FIGURE 8
Reduction in Gini coefficient due to personal income tax under different scenarios, average for Latin America
(Reynolds-Smolensky index)

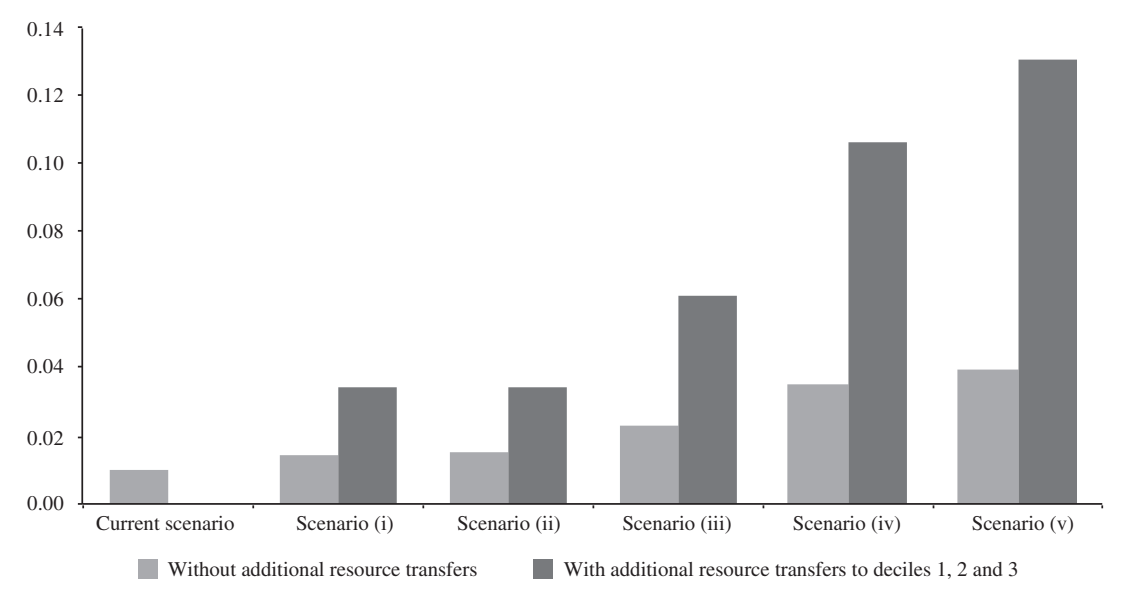

Source: Prepared by the authors, on the basis of household surveys.

Note: Scenarios: (i) Personal income tax without tax expenditures; (ii) Family tax; (iii) Standard tax; (iv) 20\% rate of tax on decile 10, and (v) $20 \%$ rate of tax on decile 10 and $10 \%$ on deciles 8 and 9.

FIGURE 9
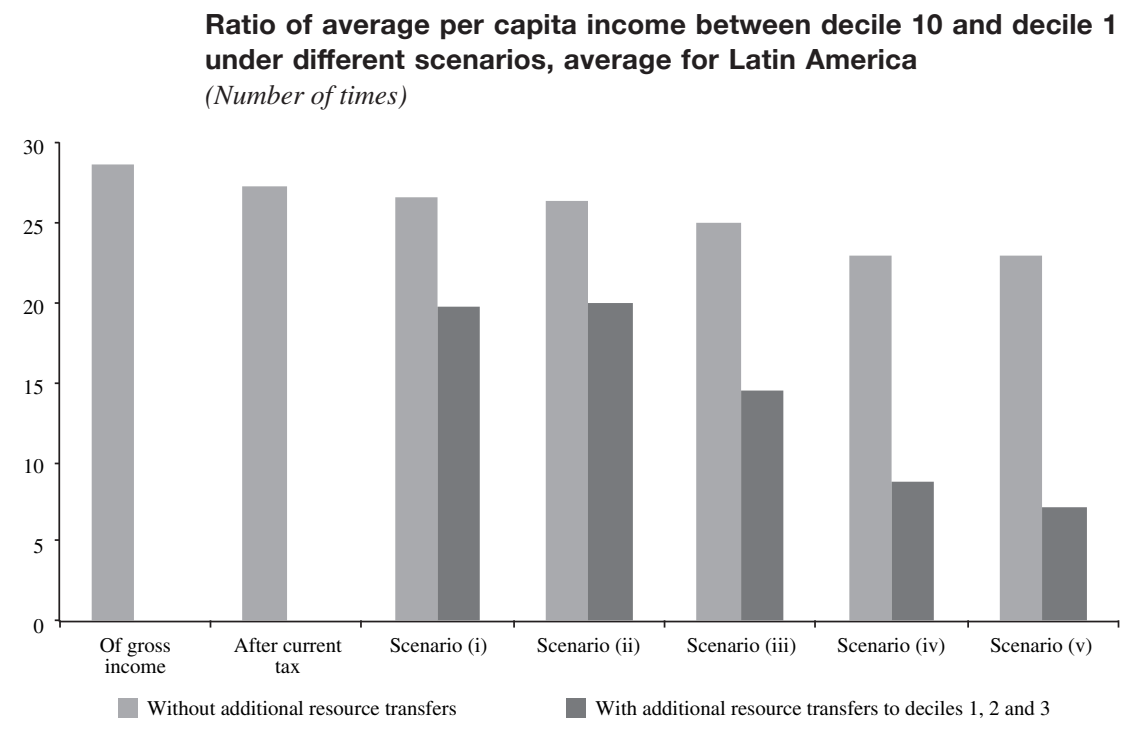

Source: Prepared by the authors, on the basis of household surveys.

Note: Scenarios: (i) Personal income tax without tax expenditures; (ii) Family tax; (iii) Standard tax; (iv) 20\% rate of tax on decile 10, and (v) $20 \%$ rate of tax on decile 10 and $10 \%$ on deciles 8 and 9 . 


\section{VII}

\section{Final remarks}

In Latin America, fiscal policy still plays a limited role in improving the distribution of disposable income. While countries of the region are starting from market income inequality levels that are only slightly higher than those of OECD countries, fiscal policy in the latter plays a significant role in reducing inequality, as the Gini coefficient drops $36 \%$ after transfers and direct taxes, compared with only $6 \%$ in Latin American countries (in absolute terms, the Gini coefficient falls 17 percentage points in OECD countries and barely three points on average across 17 Latin American countries).

Regardless of the clear differences between countries that the foregoing calculations have illustrated, on average, $61 \%$ of the reduction in the Gini coefficient in Latin America is due to public cash transfers (including pensions) and the rest comes from personal income tax and social security contributions. This indicates that income tax is one of the main areas of fiscal policy that needs to be strengthened.

The simulations of possible personal income tax reforms demonstrate that there is scope to increase the redistributive power of this tax in the region. Vertical equity improves when the main tax expenditures are phased out, as well as when a family tax regime is introduced. Imposing a standard tax, on a broad tax base, further increases the redistributive role of the tax. In the hypothetical case that countries of the region raise the effective rate on the highest earning decile to $20 \%$, the redistributive effect of personal income tax would increase considerably. If, in addition, the extra revenue raised is redistributed among lower deciles, the fiscal action would have a significant impact on the Gini coefficient.
Calculating the redistributive effect of these possible reforms reaffirms the importance of promoting measures to combat tax evasion and avoidance (particularly with regard to personal income tax); applying a similar treatment to capital income as that imposed on labour income; reducing preferential treatment; and lowering the threshold for the top rates of tax to be applied, consistently with the tax brackets in other regions.

Furthermore, if the additional revenue raised by these measures is used to supplement transfers received by the lower income deciles, it could triple the redistributive effect of fiscal policy.

In conclusion, the results of this study suggest that one of the major challenges still facing the region is improving the redistributive power of fiscal policy, in terms of both taxes and expenditure, in order to enhance equality in disposable income distribution and further reduce poverty. Broadening the study to examine transfers in kind (basically in education and health services) and applying it to different periods would help to establish a more complete picture of the impact of fiscal policy and its evolution over time.

As the distribution of "primary" income (before State intervention) is determined by a combination of legacies of tangible and material wealth and of human capital, the persistence of inequality also reflects the lack of policies capable of changing this situation in the region. Of course, as ECLAC has stressed in its equality trilogy (ECLAC, 2010, 2012b and 2014b), multiple initiatives must be deployed for structural change with equality. But redistributive fiscal policies must, undoubtedly, contribute to changing this regional stigma in the future. 


\section{Bibliography}

Altimir, O. (1987), "Income distribution statistics in Latin America and their reliability", Review of Income and Wealth, vol. 33, No. 2, New Haven, International Association for Research in Income and Wealth.

Barreix, A., M. Bes and J. Roca (2009), "Equidad fiscal en Centroamérica, Panamá y República Dominicana”, Washington, D.C., InterAmerican Development Bank (IDB)/EUROSOCIAL.

Barreix, A., J. Roca and L. Villela (2006), "La equidad fiscal en los países andinos", Washington, D.C., Inter-American Development Bank (IDB)/EUROSOCIAL.

Bosch, M., A. Melguizo and C. Pagés (2013), Better Pensions, Better Jobs: Towards Universal Coverage in Latin America and the Caribbean, Washington, D.C., Inter-American Development Bank (IDB).

Cetrángolo, O. and J.C. Gómez Sabaini (2007), "La tributación directa en América Latina y los desafíos a la imposición sobre la renta", Macroeconomía del Desarrollo series, No. 60 (LC/G.2838-P), Santiago, Economic Commission for Latin America and the Caribbean (ECLAC). United Nations publication, Sales No. S.07.II.G.159

Díaz de Sarralde, S., C. Garcimartín and J. Ruiz-Huerta (2010), "The paradox of progressivity in low-tax countries: income tax in Guatemala", cEPAL Review, No. 102 (LC/G.2468-P), Santiago.

ECLAC (Economic Commission for Latin America and the Caribbean) (2014a), "Panorama fiscal de América Latina y el Caribe: hacia una mayor calidad de las finanzas públicas" (LC/L.3766), Santiago. (2014b), Compacts for Equality: Towards a Sustainable Future (LC/G.2586 (SES.35/3)), Santiago.

(2013a), "Panorama fiscal de América Latina y el Caribe: reformas tributarias y renovación del pacto fiscal" (LC/L.3580), Santiago.

(2013b), Social Panorama of Latin America 2013 (LC/G.2580), Santiago. United Nations publication, Sales No. E.14.II.G.6

(2012a), "La medición de los ingresos en la encuesta CASEN

2011-R2", Santiago, August, preliminary version.

(2012b), Structural Change for Equality: An Integrated Approach to Development (LC/G.2524 (SES.34/3)), Santiago.

(2012c), Social Panorama of Latin America 2011 (LC/G.2514-P), Santiago. United Nations publication, Sales No. E.12.II.G.6. (2010), Time for equality: closing gaps, opening trails (LC/G.2432 (SES.33/3)), Santiago.

(2008), Social Panorama of Latin America 2007 (LC/G.2351-P), Santiago. United Nations publication, Sales No. E.07.II.G.124.
Gómez Sabaini, J.C. and D. Morán (2013), "Política tributaria en América Latina: agenda para una segunda generación de reformas", Macroeconomía del Desarrollo series, No. 133 (LC/L.3632), Santiago, Economic Commission for Latin America and the Caribbean (ECLAC)

Goñi, E., J. Lopéz and L. Servén (2011), "Fiscal redistribution and income inequality in Latin America”, World Development, vol. 39, No. 9, Amsterdam, Elsevier.

Higgins, S. and others (2013), "Social spending, taxes and income redistribution in Paraguay", CEQ Working Paper, No. 11.

Jorratt, M. (2011), "Evaluando la equidad vertical y horizontal en el impuesto al valor agregado y el impuesto a la renta: el impacto de reformas tributarias potenciales. Los casos del Ecuador, Guatemala y el Paraguay", Macroeconomía del Desarrollo series, No. 113 (LC/L.3347), Santiago, Economic Commission for Latin America and the Caribbean (ECLAC).

(2010), "Equidad fiscal en Chile: un análisis de la incidencia distributiva de los impuestos y el gasto social", Equidad Fiscal en Brasil, Chile, Paraguay y Uruguay, Washington, D.C., InterAmerican Development Bank (IDB).

Joumard, I., M. Pisu and D. Bloch (2012), "Less income inequality and more growth - Are they compatible? Part 3. Income redistribution via taxes and transfers across OECD countries", OECD Economics Department Working Papers, No. 926, OECD Publishing.

Lustig, N., C. Pessino and J. Scott (2013), "The impact of taxes and social spending on inequality and poverty in Argentina, Bolivia, Brazil, Mexico, Peru and Uruguay: An overview", CEQ Working Paper, No. 13.

OECD (Organization for Economic Cooperation and Development) (2008), Growing Unequal? Income Distribution and Poverty in OECD Countries, Paris, OECD Publishing.

OECD/ECLAC/CIAT (Organization for Economic Cooperation and Development/Economic Commission for Latin America and the Caribbean/Inter-American Center of Tax Administrations) (2014), Estadísticas tributarias de América Latina, OECD Publishing.

Ter-Minassian, T. (2012), "More than revenue: main challenges for taxation in Latin America and the Caribbean", Policy Brief, No. IDB-PB-175, Washington, D.C, Inter-American Development Bank (IDB).

Urzúa, C.M. (ed.) (2012), Fiscal Inclusive Development: Microsimulation Models for Latin America, Mexico City, Monterrey Institute of Advanced Technological Studies. 